\title{
Puritan's progress
}

\author{
JAMES HOWIE
}

Commended to me as "a good read," John Vaizey's book is certainly that. Much more, however, it is the incredible account of an incredible man's incredible pilgrimage. In politics he came all the

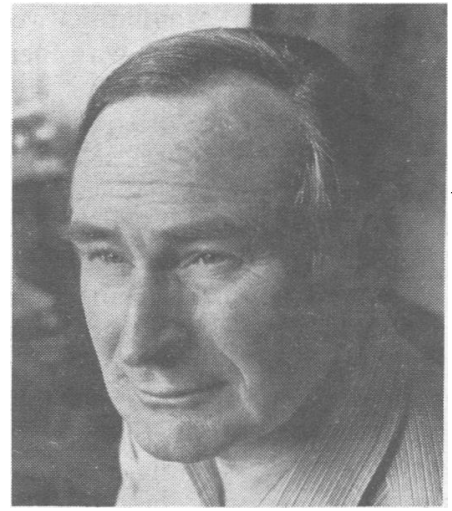
way from the national executive of the Fabian Society to the House of Lords, where, rejecting socialism in 1978 , he accepted the Tory whip and became one of Margaret Thatcher's staunchest admirers and one of her close advisers. Academically he went all the way from a wartime emergency grammar school in Lewisham via the universities of Cambridge and Oxford to Brunel, where he was a professor of economics and served on two government commissions on educational matters. Wherever

John Vaizey.

he went he made friends with incredible ease, and they were most often to be seen surrounding him with cheerful laughter at his lively wit. Unfortunately, an impression grew up that his capacity for making friends was equalled only by his readiness to discard them when they had served his purpose. That judgment is just possibly too severe, but it is not difficult to see how it came about. Sadly, he died in 1984 aged 54.

The main section of the book is a reprint of his Scenes from Institutional Life, which is justly decribed in the dust cover as "a minor classic." It is in fact a moving account of the physical and mental sufferings of a child of 14 over a period of one year and seven months (1943-5) during which he was being treated by the very painful methods then available for osteomyelitis of the spine. The physical suffering and the fear caused by the dangers of the blitz on London and the $\mathrm{V}$ bombs were by no means what most distressed him. His writing about the atmosphere and workings of the hospital is full of bitterness and condemnation. The kindly and popular nursing sister who loved her boys and treated them as individuals was replaced by a severe sister when the patients were evacuated from London. The popular sister was not highly regarded by the medical chiefs because of "beds all over the place, boys out of bed...." The severe sister, who enforced all sorts of petty tyrannies, was regarded by the doctors as "an excellent sister" because she played up to them and entertained them handsomely. Eventually there was an outburst by the boys against the severe sister, who had to be placated with an "apology" so grudgingly and gracelessly given that despite her apparent victory "she was a shaken woman." But bitterness left its legacy.

Vaizey's experience-alas not too exceptional-led him to conclude that the isolation of a hospital can be a terrible thing. All in it are under the power of some petty despot; and the corrupting desire to exercise power over other people is so easily gratified that only the most saintlike among senior doctors and nurses know how to treat patients and juniors as people and not as things. Hospitals, he warns us, strip patients of their dignity; and he feels compelled to generalise that all manifestations of institutional life are equally horrible. Everything in our social life is capable of being institutionalised, and our political energies should be devoted to restraining institutions no matter how humanitarian and well meaning they are. In hospitals, especially, isolation is the problem favouring the immature and unstable and causing them to mask their insufficiency with rigid rules and authoritative discipline. Those within institutions who retain a capacity for human muddle and calm maturity are rejected by the heads of the establishments and are in fact the sports of the system. Oddly, although by his own admission he became "a deeply-flawed Puritan" and, indeed, a devout high churchman, he emphatically rejected the Christian view that suffering has redemptive value and that undeserved suffering has supreme redemptive value.

Vaizey exaggerates, of course. That is his way. But we should all be warned because his exaggeration forces home a truth. Each one of us, especially the dedicated, has within himself or herself elements of cruelty, insensitivity, and stupidity that clamour for expression.

Scenes from Institutional Life and Other Writings. J Vaizey. (Pp 176; £12.95.) London: Weidenfeld and Nicolson, 1987. ISBN 0-29778868-X.

\section{Following unchaste footsteps}

\section{TRISHA GREENHALGH}

I never liked the story we got at school that when the early cavewomen had trouble carrying the berries home Man the Hunter downed tools and invented pottery. Margaret Alic has written a book that puts women scientists back into history and has spiced it with tales of the men who stole their glory.

It is no surprise that Marie Curie does not stand alone among the great men of the past. The book's interest does not lie in the rediscovery of other women scientists. It is interesting because it places their lives and achievements in the context of societies in which the quest for scientific knowledge was denied to women in general and to wives and mothers in particular.

For the most part, successful women scientists have lived a life apart from mainstream society. From the early Pythagorean
Brotherhood (a misnomer as it welcomed women and men on equal terms and earned Pythagoras the title "the feminist philosopher") through mediaeval convents to the eccentric eighteenth century Bluestocking Society (which, incidentally, took its name from the unconventional dress of one of its male members) women scientists found themselves niches where they could escape traditional expectations and get on with what they were good at. Some of these niches were more bizarre than others. In classical Athens, for example, there were

. . . high class prostitutes, the hetairai (companions to men), [who] were usually foreign-born women barred by law from marrying Athenian citizens. The hetairai were often educated, 


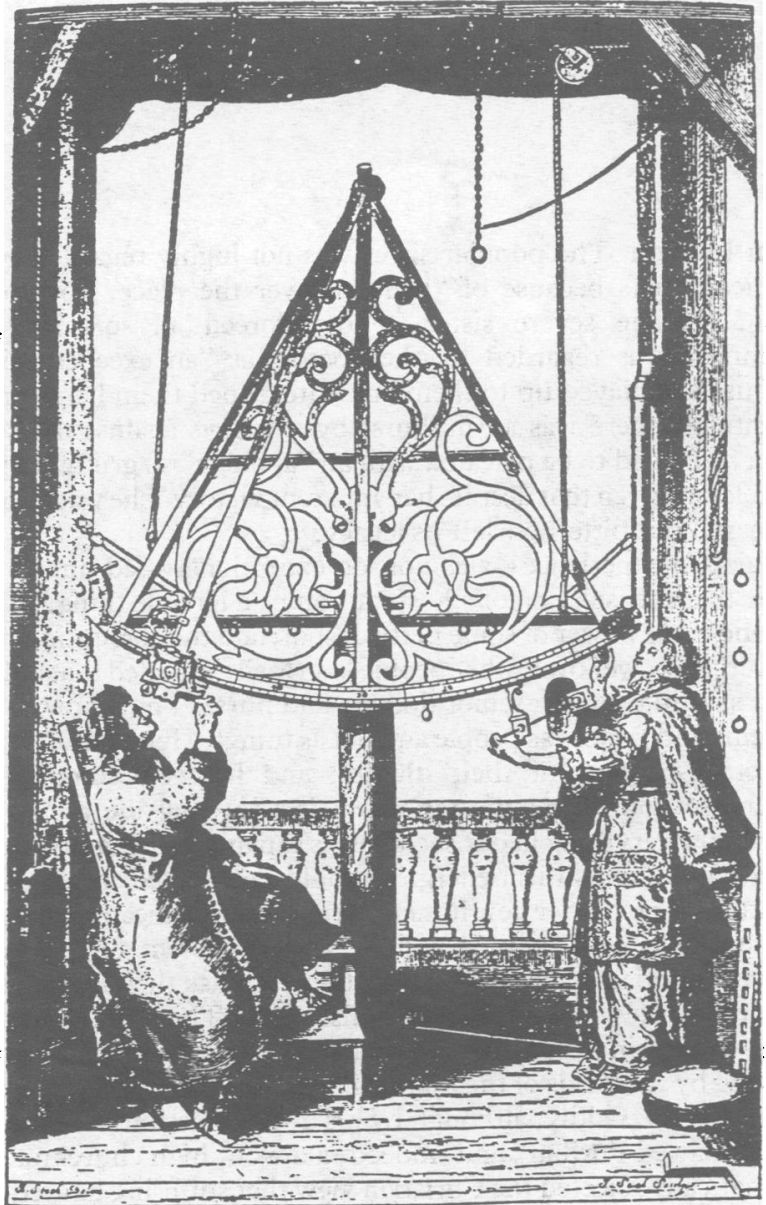

Elizabeth Hevelius and her husband Johannes observing with a large brass sextant. artistic and intellectual, forming a class in their own right, for they were free from the restrictions imposed on the wives of Athenian citizens ( $\mathrm{p} 25)$.

Before the advent of universities education was open to anyone who could afford books and a tutor, and experimental science to anyone with the wherewithal to test hypotheses. We are told of Byzantine empresses who turned their private apartments into chemistry laboratories, and of Queen Cleopatra, whose contribution to science was the killing of female slaves at various stages after conception in order to chart the development of the fetus. By the seventeenth century social mores had reduced the pastimes of scientifically minded aristocratic ladies to "examining "wee beasties' with their microscopes and the distant heavens with their telescopes."

The struggle to gain credibility in a male world has often been an uphill one. Women philosophers in ancient Greece were said by a critic of the day to "smear it [philosophy] with shameful stains, trample it with unchaste feet, and plunge it into filthy sewers"-and this in a treatise entitled Praising Famous Women (quoted on $\mathrm{p} 27$ ). The fourth century scientist and astronomer Hypatia, from whom the book takes its title, was not well received by the growing Christian community. Her grisly demise-in which a band of men stripped her naked and skinned her inside a church-marks the end of ancient science and the beginning of the Dark Ages.

Ms Alic has revealed women who published under male pseudonyms, credited their discoveries to their husbands, or (with the ultimate in false modesty) claimed that all their thoughts were a vision from God. She catches a twentieth century male historian in the circular argument that an ancient medical manuscript was so deeply scientific that it could not possibly have been written by a woman. Some would say that this book is eclectic to the point of being prejudiced. As such, it is redressing a balance, and it does so in a way that is thoroughly researched, well referenced, and refreshingly free from feminist jargon.

Hypatia's Heritage. A History of Women in Science from Antiquity to the Late Nineteenth Century. M Alic. (Pp 240; figs; 44.95 paperback.) London: The Women's Press, 1986. ISBN 0-7043-3954-4.

\title{
Here we are again
}

\author{
ALEX PATON
}

In a recent interview Dennis Potter, the television playwright, said that he employed the immediate past not to induce nostalgia but "to intrude upon the present." Wherever you care to look in Geoffrey Rivett's fascinating account of the development of the London hospitals over the past 150 years you will appreciate the significance of this statement. Today's doctors, haunted by RAWP, reorganisation, financial cuts, and redundancy may derive a mite of comfort from the fact that it has all happened before.

Early in the nineteenth century reformers began to realise that London's hospitals were haphazardly distributed, available only to a minority of the population, and mostly working in isolation, not always to the highest professional standards. In Paris by contrast they were controlled by a central body and generously financed by the local authorities. Of course, hospitals by themselves could do little since, as the Lancet pointed out, "the great majority of acute illnesses of the poor are directly caused by ... conditions arising out of the utter neglect of sanitary regulations." Today we use euphemistic terms like "environmentally disadvantaged." But as London grew, and people moved out from the centre where the original voluntary hospitals had been built, the development of local hospitals seldom kept pace with demand.

\section{Cash and cuts}

The voluntary hospitals relied on contributions from the public, and as the years went by and medicine advanced into expensive technology it became increasingly difficult to raise enough money. (Readers who were students before the introduction of the National Health Service will remember-with nostalgia? - the flag days.) Competition between hospitals was intense and damaging. Lack of funds led to patients being turned away and wards closed ( 150 beds were out of use at Guy's by 1887) and to complaints-100 years ago, note-about the extravagant use of expensive drugs and equipment. The Middlesex Hospital board in 1821 asked its surgeons to restrict the use of leeches, then running at nearly 100 a day, just as now our managers try to ration pacemakers and artificial joints. From the 1850 s attempts to persuade the voluntary hospitals to move out of metropolitan London were opposed by the consultants who did not wish to be too far away from the west end. King's College Hospital which did move to Denmark Hill found it difficult at first to make ends meet.

The infirmaries increasingly challenged the voluntary hospitals. Established originally to treat only the sick among the destitute, by 